\title{
A systematic review and meta-analysis of Harmonic Focus in thyroidectomy compared to conventional techniques
}

\author{
Hang Cheng ${ }^{1}$, Ireena Soleas ${ }^{2}$, Nicole C. Ferko ${ }^{2}$, Jeffrey W. Clymer ${ }^{1 *}$ and Joseph F. Amaral ${ }^{1}$
}

\begin{abstract}
Introduction: Several meta-analyses have been performed comparing the use of a variety of ultrasonic devices in thyroidectomy to conventional procedures. These studies have shown the superiority of ultrasonic devices for most outcomes studied including faster operative time and less blood loss, and equivalent or better safety for recurrent laryngeal nerve paresis and hypocalcemia. The current work is the first to examine a single ultrasonic device specifically designed for thyroid surgery, the Harmonic Focus, in order to confirm its efficacy and safety in thyroidectomy.

Methods: A comprehensive literature search without language restrictions was performed for randomized clinical trials comparing Harmonic Focus and conventional clamp, cut and tie in thyroidectomy. Outcome measures included operating time, blood loss, post-operative pain, length of hospital stay, hypocalcemia and recurrent laryngeal nerve paresis. Risk of bias was analyzed for all studies. Meta-analysis was performed using random effects models with the inverse-variance method for mean differences of continuous variables and the Mantel-Haenszel method for risk ratios of dichotomous variables.
\end{abstract}

Results: A total of 14 studies met the inclusion criteria. Harmonic Focus reduced operative time by 29 min, a $31 \%$ decrease $(p<0.001)$, intra-operative blood loss by $45 \mathrm{ml}(p<0.001)$, post-operative pain $(p<0.001)$, length of hospital stay by 0.68 days $(p=0.005)$, drainage volume by $29 \mathrm{ml}(p=0.01)$, and occurrence of transient hypocalcemia by $40 \%(p=0.001)$. There were no significant differences between Harmonic Focus and conventional procedures in rate of persistent hypocalcemia, or rates of transient and persistent recurrent laryngeal nerve paresis.

Conclusion: This is the first meta-analysis of Harmonic Focus in thyroid surgery. In agreement with meta-analyses previously performed on ultrasonic devices, use of the Harmonic Focus has been shown to be a more effective surgical procedure compared to conventional methods in thyroidectomy. The low occurrence of hypocalcemia and recurrent laryngeal nerve paresis confirms that Harmonic Focus can improve thyroidectomy efficiency without increasing the risk of complications.

Keywords: Harmonic Focus, Ultrasonic, Meta-analysis, Thyroidectomy

\footnotetext{
* Correspondence: jclymer@its.jnj.com

${ }^{1}$ Ethicon Inc, 4545 Creek Rd, Cincinnati, OH 45242, USA

Full list of author information is available at the end of the article
} 


\section{Introduction}

Ultrasonic cutting and coagulation of soft tissues was introduced in 1991 with a primary focus on laparoscopic surgery in general and cholecystectomy in particular $[1,2]$. There then followed a rapid evolution and adoption of the technology for vessel sealing that resulted in widespread use in a variety of intra-abdominal procedures including colectomy [3], fundoplication [4], and hysterectomy [5]. By the late 1990s and early 2000's, endocrine and head and neck surgeons had adopted such devices for thyroid surgery noting decreased operating times [6]. Since then numerous randomized control trials (RCTs), large case series and numerous meta-analyses have been published confirming the reduction in operating time [7]. Furthermore, they have shown less blood loss (albeit not clinically significant), smaller incisions, less postoperative pain, reduced hospitalization and less drainage. Perhaps most importantly, studies that have evaluated the economic impact of using ultrasonic energy have concluded that there is overall cost savings when using such devices $[8,9]$.

A drawback of these studies is that they have used a variety of ultrasonic devices including Ultracision, Ace and Focus. However, since its introduction in 2007, the only specifically designed and approved device for use in thyroid and head and neck surgery is Harmonic Focus ${ }^{\circ}$ (Ethicon Inc., Cincinnati OH). No meta-analysis or systematic review has been published to date evaluating specifically the impact of Harmonic Focus on the outcomes of thyroid surgery. Furthermore, some controversy exists in the literature concerning the impact of ultrasonic devices in general and Harmonic Focus in particular on parathyroid gland and recurrent laryngeal nerve function when these devices are used.

The purpose of this systematic review and metaanalysis is to answer two questions. First, what is the impact of Harmonic Focus on overall thyroid surgery outcomes when compared to the most commonly used clamp, cut and tie method that includes monopolar and or bipolar electrosurgery? Second, what impact does Harmonic Focus have on parathyroid and recurrent laryngeal nerve function following thyroid surgery?

\section{Methods}

Twenty-one databases were systematically searched, including MEDLINE via PubMed, EMBASE, the Cochrane Central Register of Controlled Trials (CENTRAL), and 18 other national databases (Table 1). Reference lists of retrieved articles were reviewed and additional comprehensive searches were conducted through Google Scholar and Research-Gate. Publications of all languages were considered in the systematic review.

The PICOS categories (i.e., population, intervention, comparator, outcomes, and study design) were used to
Table 1 List of databases and search periods included in systematic search

\begin{tabular}{|c|c|}
\hline Databases & Search dates \\
\hline EMBASE & \multirow[t]{3}{*}{ Until 30th September 2014} \\
\hline MEDLINE (via PubMed) & \\
\hline CENTRAL & \\
\hline LILACS IBECS & \multirow{9}{*}{$\begin{array}{l}\text { Conducted between 26th and } \\
\text { 30th September } 2013\end{array}$} \\
\hline $\begin{array}{l}\text { African Index Medicus, Index Medicus } \\
\text { for Eastern and Mediterranean Region, } \\
\text { Index Medcus for South-East Asia } \\
\text { Region and The Western Pacific Region } \\
\text { Index Medicus }\end{array}$ & \\
\hline African Journals Online & \\
\hline IndMed (India) & \\
\hline PakMediNet (Pakistan) & \\
\hline Türk Tip Veri Tabani (Turkey) & \\
\hline Krack (Croatia) & \\
\hline SID and IrMedex (Iran) & \\
\hline KoreaMed (Korea) & \\
\hline ICHUSHI-web (Japan) & Until 22nd April 2013 \\
\hline Wanfang, Cqvip, CNKI (China) & Until 16th April 2013 \\
\hline
\end{tabular}

define study inclusion criteria. All published RCTs comparing the use of Harmonic surgical devices to conventional methods, such as monopolar or bipolar electrosurgery and suture, clips, or knot-tying in human subjects, for all surgery types, were considered for inclusion (Table 2). Benign and malignant disease were included if no lymph node dissection was performed. Full-text papers were excluded if, they were not a RCT, the principal surgical procedure was not thyroidectomy, devices other than the Harmonic Focus were used, and if lymphadenectomy, or only partial thyroidectomy, was conducted. The eligibility of each publication was evaluated by two independent reviewers (IS, NCF) and a third reviewer $(\mathrm{HC})$ was consulted in the case of disagreements regarding study inclusion. When necessary, study authors were contacted for additional methodological details to confirm whether the study was randomized.

Study details (i.e., baseline characteristics and outcomes) of included publications were extracted through a standardized data extraction form. Two reviewers extracted data independently and any inconsistencies were resolved by consensus or by consultation with a third reviewer. Non-English publications were translated and data extraction was completed. Data extraction by one reviewer was subsequently cross-checked by a second reviewer.

The following clinical outcome measures were included: (1) operating time, (2) intra-operative blood loss, (3) postoperative pain, (4) length of hospitalization, (5) volume of drainage fluid, (6) hemorrhage requiring surgery, (7) 
Table 2 Study and baseline characteristics for studies meeting inclusion criteria for open total thyroidectomy

\begin{tabular}{|c|c|c|c|c|c|c|c|}
\hline Reference & Country & Interventions evaluated & $\mathrm{n}$ & $\begin{array}{l}\text { Mean Age } \pm \text { SD or } \\
\text { (range) }\end{array}$ & $\begin{array}{l}\% \\
\text { Male }\end{array}$ & $\begin{array}{l}\text { Study length } \\
\text { (months) }\end{array}$ & Included endpoints ${ }^{\mathrm{a}, \mathrm{b}}$ \\
\hline \multirow[t]{2}{*}{ Askar 2011 [19] } & \multirow[t]{2}{*}{ Turkey } & Harmonic Focus & 65 & $41.81 \pm 13.4$ & $16.9 \%$ & \multirow[t]{2}{*}{24} & \multirow{2}{*}{$\begin{array}{l}\text { Operating time, Intra-operative blood loss, Length of stay, } \\
\text { Post-operative pain, Drainage fluid volume, Hemorrhage } \\
\text { requiring surgery, } \\
\text { Hypocalcemia, RLN paresis }\end{array}$} \\
\hline & & Knot-tying with electrocautery & 65 & $36.24 \pm 12.62$ & $24.6 \%$ & & \\
\hline \multirow{2}{*}{$\begin{array}{l}\text { Cannizzaro } 2014 \\
{[12]}\end{array}$} & \multirow[t]{2}{*}{ Italy } & Harmonic Focus & 141 & \multirow[t]{2}{*}{53 (12 to 81$)$} & \multirow[t]{2}{*}{$16.0 \%$} & \multirow[t]{2}{*}{24} & \multirow{2}{*}{$\begin{array}{l}\text { Operative time, Intra-operative blood loss, Length of stay, } \\
\text { Serum calcium, Hypocalcemia, RLN paresis }\end{array}$} \\
\hline & & $\begin{array}{l}\text { Monopolar or bipolar electrocautery, } \\
\text { suture and clips }\end{array}$ & 124 & & & & \\
\hline \multirow{2}{*}{$\begin{array}{l}\text { Di Renzo } 2010 \\
\text { [18] }\end{array}$} & \multirow[t]{2}{*}{ Italy } & Harmonic Focus & 31 & $50.5 \pm 12.1$ & $26.0 \%$ & \multirow[t]{2}{*}{8} & \multirow{2}{*}{$\begin{array}{l}\text { Operating time, Length of stay, Hemorrhage requiring surgery, } \\
\text { Hypocalcemia, RLN paresis }\end{array}$} \\
\hline & & Classic suture ligation & 31 & $51.5 \pm 13.7$ & $22.0 \%$ & & \\
\hline \multirow{2}{*}{$\begin{array}{l}\text { Docimo } 2012 \\
{[16]}\end{array}$} & \multirow[t]{2}{*}{ Italy } & Harmonic Focus & 100 & 46 (16 to 70$)$ & $30.0 \%$ & \multirow[t]{2}{*}{24} & \multirow{2}{*}{$\begin{array}{l}\text { Operating time, Hemorrhage requiring surgery, Hypocalcemia, } \\
\text { RLN paresis, Wound seroma }\end{array}$} \\
\hline & & Conventional clamp and tie & 100 & & $40.0 \%$ & & \\
\hline \multirow[t]{2}{*}{ Duan 2013 [14] } & \multirow[t]{2}{*}{ China } & Harmonic Focus & 389 & $48.5 \pm 21.8$ & $4.89 \%$ & \multirow[t]{2}{*}{ Not reported } & \multirow{2}{*}{$\begin{array}{l}\text { Operating time, Length of stay, Hemorrhage requiring surgery, RLN } \\
\text { paresis, Hypocalcemia }\end{array}$} \\
\hline & & Suture/clip ligation withelectrocautery & 389 & $50.1 \pm 19.3$ & $5.82 \%$ & & \\
\hline \multirow[t]{2}{*}{ Ferri 2011 [20] } & \multirow[t]{2}{*}{ Italy } & Harmonic Focus & 50 & 48.7 (21 to 73 ) & $44.0 \%$ & \multirow[t]{2}{*}{12} & \multirow{2}{*}{$\begin{array}{l}\text { Operating time, Post-operative pain, Length of stay, Drainage fluid } \\
\text { volume, Hypocalcemia, RLN paresis }\end{array}$} \\
\hline & & Knot tying with electrocautery & 50 & 51.4 (23 to 72$)$ & $38.0 \%$ & & \\
\hline \multirow{2}{*}{$\begin{array}{l}\text { Gentileschi } 2011 \\
{[21]}\end{array}$} & \multirow[t]{2}{*}{ Italy } & Harmonic Focus & 43 & $49.0 \pm 13$ & $20.9 \%$ & \multirow[t]{2}{*}{12} & \multirow{2}{*}{$\begin{array}{l}\text { Operating time, Length of stay, Hemorrhage requiring surgery, } \\
\text { Hypocalcemia, RLN paresis }\end{array}$} \\
\hline & & $\begin{array}{l}\text { Conventional technique (knot-tying } \\
\text { with electrocautery) }\end{array}$ & 38 & $48.0 \pm 15$ & $10.5 \%$ & & \\
\hline \multirow{2}{*}{$\begin{array}{l}\text { Konturek } 2012 \\
{[9]}\end{array}$} & Poland & Harmonic Focus & 41 & $41.1 \pm 7.5$ & $17.1 \%$ & 11 & Operating time, Intra-operative blood loss, Length of stay, Hemorrhage \\
\hline & & Bipolar electrocautery and clip & 41 & $42.0 \pm 7.5$ & $19.5 \%$ & & \\
\hline Materazzi 2013 & Italy & Harmonic Focus & 141 & $51.68 \pm 12.2$ & $19.5 \%$ & 55 & Operating time, Length of stay, Hemorrhage requiring surgery, \\
\hline & & Conventional clamp and tie & 127 & $53.97 \pm 12.5$ & $27.6 \%$ & & \\
\hline Miccoli 2010 & Italy & Harmonic Focus & 31 & 48.6 (29 to 67$)$ & $29.0 \%$ & Not reported & Operating time, Volume of drainage fluid, Post-operative pain, RLN \\
\hline & & Suture/clip ligation with electrocautery & 31 & $53.2(18$ to 75$)$ & $25.8 \%$ & & \\
\hline Mourad 2011 & Belgium & Harmonic Focus & 34 & $50.0 \pm 15$ & $23.5 \%$ & 6 & Operating time, Intra-operative blood loss, Hypocalcemia, RLN paresis \\
\hline & & $\begin{array}{l}\text { Monopolar electrocautery with clamp } \\
\text { and tie }\end{array}$ & 34 & $47.0 \pm 12$ & $23.5 \%$ & & \\
\hline Pons 2009 [8] & France & Harmonic Focus & 20 & $55.0 \pm 11$ & $20.0 \%$ & Not reported & Operating time, Intra-operative blood loss, Hemorrhage requiring \\
\hline & & Conventional clamp and tie & 20 & & & & \\
\hline Sista 2012 [13] & Italy & Harmonic Focus & 130 & $49.3(32$ to 76$))$ & $23.8 \%$ & 14 & Operating time, RLN paresis, Hypocalcemia \\
\hline & & $\begin{array}{l}\text { Monopolar or bipolar diathermy and } \\
\text { ligature }\end{array}$ & 131 & 51.1 (39 to 78) & $22.1 \%$ & & \\
\hline Soroush 2013 & Iran & Harmonic Focus & 33 & $38.7 \pm 13.5$ & $48.5 \%$ & 12 & Operating time, Intra-operative blood loss, Length of stay, RLN paresis \\
\hline & & Conventional clamp and tie & 35 & $43.2 \pm 14.5$ & $54.3 \%$ & & \\
\hline
\end{tabular}


hypocalcemia (transient and persistent), (8) recurrent laryngeal nerve (RLN) paresis (transient and persistent), and (9) wound seroma. Inclusion criteria for the persistent RLN paresis parameter required at least six months follow-up unless RLN paresis was not reported prior to six months. RLN paresis needed to be determined via laryngoscopy. In studies where results were reported for transient RLN paresis, but not persistent RLN paresis, it was assumed that there were zero cases of the persistent type. The same assumption was applied to the transient and persistent hypocalcemia outcome. Both clinically- and chemically-determined hypocalcemia were included in the hypocalcemia parameter. The standard deviation (SD) variance measure was not reported in one study [10] for operating time. Study authors were not contacted to retrieve missing data, however, standard methods provided by Cochrane [11] were used to impute the missing variance measure in this study.

The Cochrane Collaboration tool [11] for assessing risk of bias was used to evaluate the quality of the included studies. Based on seven pre-specified domains (sequence generation, allocation concealment, blinding of participants and personnel, blinding of outcome assessment, incomplete outcome data, selective outcome reporting, and other sources of bias), publications were scored as having low, unclear, or high risk of bias. Final quality assessments were based on the combination of these factors and individual study characteristics. Two authors independently assessed the study quality and inconsistencies were resolved through consensus or by discussion with a third author.
Review Manager (Version 5.3, The Nordic Cochrane Centre, The Cochrane Collaboration, Copenhagen, Denmark, 2014) was used to perform the meta-analysis. The inverse-variance method was used to calculate the mean differences (MD) for continuous outcomes (operating time, intra-operative blood loss, post-operative pain, length of hospitalization, volume of drainage fluid). Risk ratios (RR) were calculated for dichotomous outcomes (hemorrhage requiring surgery, wound seroma, transient hypocalcemia, persistent hypocalcemia, transient RLN paresis, persistent RLN paresis) using the Mantel-Haenszel method. The meta-analysis used a random effects model and forest plots for all included outcomes were generated using Review Manager. Study heterogeneity was evaluated through the $\chi^{2}$ test and $I^{2}$ measure.

The Harmonic Focus was compared to conventional methods in the primary analysis. Sensitivity analyses were conducted for the imputation of missing variance measures, where studies requiring imputation were excluded [10]. Further sensitivity analyses were completed for study quality, where studies with unclear or high risk of bias across several measures were excluded [8, 12-15]. Sensitivity analyses excluding studies that did not include electrocautery as part of the conventional technique $[8,15-18]$ were also performed.

\section{Results}

The systematic search resulted in the identification of 4542 total records, of which 4153 were excluded following title and abstract screening (Fig. 1). Of the 389 full text articles retrieved and reviewed, 375 were further

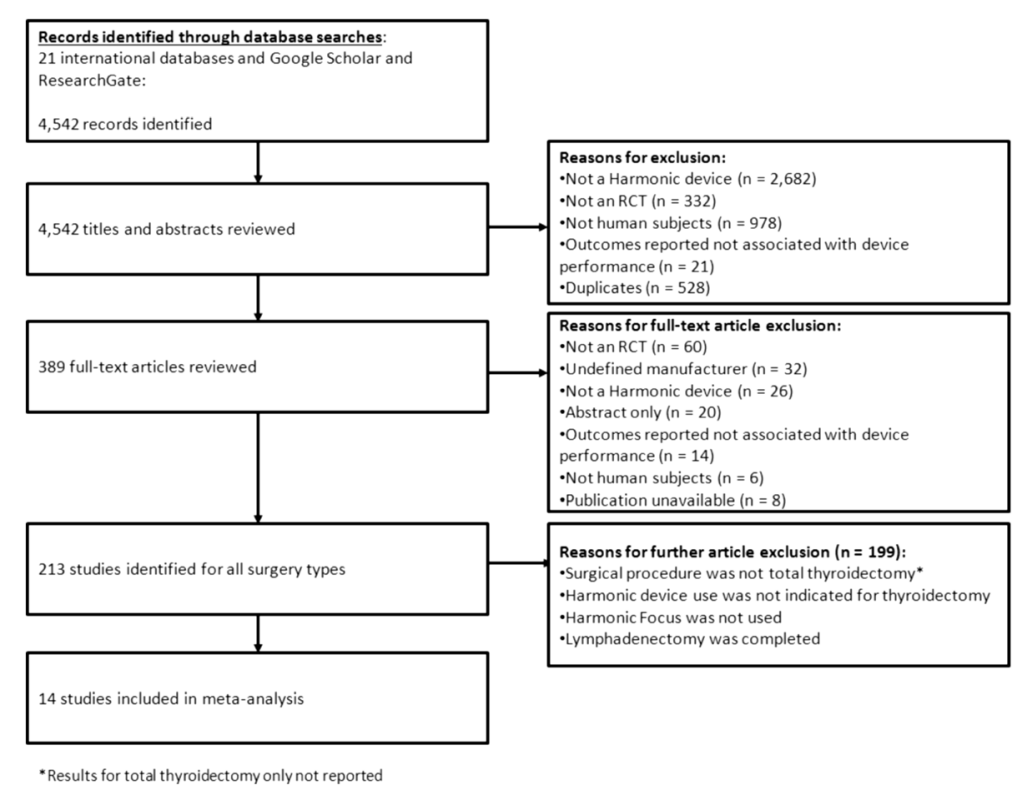

Fig. 1 PRISMA diagram for the systematic literature review 
excluded if studies were non-RCTs, had an undefined manufacturer, did not use Harmonic Focus, the publication was unavailable and had nonhuman subjects, or the surgical procedure was not total thyroidectomy. Overall, 14 studies consisting of 2516 patients in total reporting on Harmonic device (Focus) use in total thyroidectomy were included in the meta-analysis [8-10, 12-22].

Study characteristics are summarized in Table 2 . The included studies ranged in sample size from 40 to 778 , and study length spanned from 6 to 55 months. In all studies, the Harmonic Focus surgical device was compared to conventional thyroidectomy techniques. In total, four studies $[8,15-17]$ compared the Focus to conventional clamp and tie; one study [18] compared to classic suture ligation; three studies [19-21] compared to knot tying with electrocautery; and six studies $[9,10,12-14,22]$ compared to monopolar or bipolar electrocautery with one or more of sutures, clips, or clamp and tie. Total and partial thyroidectomy was performed in one study [13]; however, outcome results for partial thyroidectomy were not included. Of the 14 included studies, the majority were European, with 8 studies from Italy alone. Studies typically reported a wide range of outcomes. All included studies assessed operating time [8-10, 12-22], while intra-operative blood loss was reported in six studies $[8,9,12,15,19,22]$. Three studies assessed post-operative pain based on a visual analogue scale (VAS) $[10,19,20]$, nine studies reported the length of hospitalization $[9,12,14,15,17-21]$ and three studies reported on drainage volume $[10,19,20]$. Overall complication rate was not estimable as the two studies informing the analysis were assumed to have zero complications $[9,13]$. Instead, separate outcomes were reported for hemorrhage requiring surgery $[8,9,14,16-19,21]$, transient and persistent hypocalcemia $[8,9,12-14,16-22]$, transient and persistent RLN paresis [8-10, 12, 14-22], and wound seroma $[9,16]$. Hypocalcemia was chemicallydetermined in 11 studies [8-10, 12, 14, 16-20, 22] and clinically-determined in two studies $[13,21]$. One study did not specify whether hypocalcemia was chemically- or clinically-determined [15].

The risk of bias varied across the included studies. The overall results of the risk of bias assessments are reported in Fig. 2 and individual study quality assessments are summarized in Table 3. Randomization method was known in nine studies [8-10, 12, 16, 17, 19-22]. Three studies described randomization through the use of envelopes [10, 12, 17], two used a random permuted block design $[9,22]$, and two described the use of a drawing technique $[8,21]$. One study used a computer-generated schedule [19] and one described a fixed simple randomization method [20]. Six studies $[9,10,12,17,19,22]$ described concealment of the randomization sequence. Blinding of patients to the surgical technique was reported in six studies $[8-10,14,15,20]$, one study [22] reported blinding of the surgeon to the surgical technique, and three studies $[9,10,19]$ described blinding of outcome assessors. Risk of performance bias was deemed low in non-blinded studies, as outcomes were considered objective and unlikely to be affected by a lack of blinding. There were no patient withdrawals in seven studies $[8,9,12,16-18,20]$ and one study [22] reported exclusions, but was assumed to have no clinically relevant impact. Reporting of attritions or exclusions was insufficient in six studies [10, 13-15, 19, 21]. Selective reporting remained unclear in nine studies $[9,10,14-18,20,21]$, while three studies were deemed to have a high risk of bias as certain outcomes noted in protocol were not included in the results $[8,12,13]$.

\section{Operating time}

Mean operating time (Harmonic Focus: $66.08 \mathrm{~min}$, conventional technique: $95.26 \mathrm{~min}$ ) was statistically significantly reduced by $29.13 \mathrm{~min}(95 \% \mathrm{CI}$ : -36.73 to -21.53 ; $P<0.00001 ; 14$ studies; $I^{2}=96 \%$ ), a $30.6 \%$ decrease with

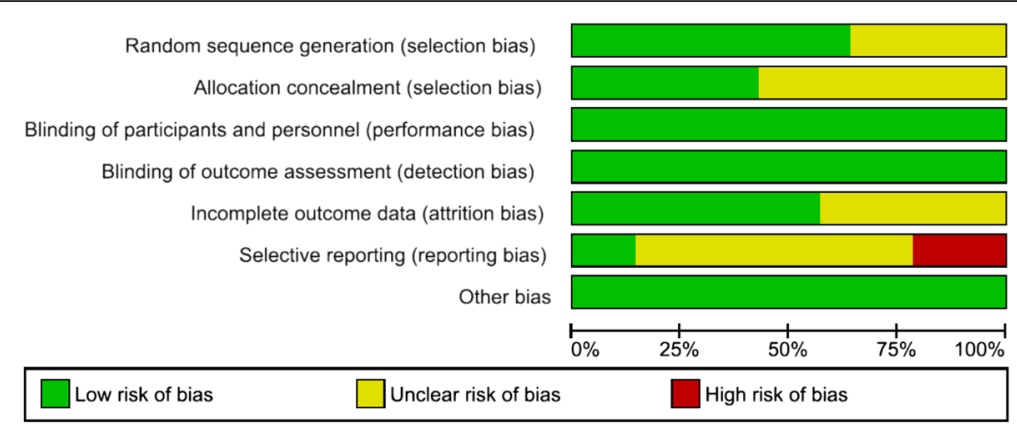

Fig. 2 Risk of bias assessment for studies meeting inclusion criteria 
Table 3 Qualitative risk of bias assessment summary

\begin{tabular}{|c|c|c|c|c|c|c|c|}
\hline Study & $\begin{array}{l}\text { Sequence } \\
\text { generation }\end{array}$ & $\begin{array}{l}\text { Allocation } \\
\text { concealment }\end{array}$ & $\begin{array}{l}\text { Blinding of personnel } \\
\text { and participants }\end{array}$ & $\begin{array}{l}\text { Blinding of } \\
\text { outcomes }\end{array}$ & $\begin{array}{l}\text { Incomplete outcome } \\
\text { data addressed }\end{array}$ & $\begin{array}{l}\text { Free of selective } \\
\text { reporting }\end{array}$ & $\begin{array}{l}\text { Free of other } \\
\text { bias }\end{array}$ \\
\hline Askar 2011 [19] & Yes & Yes & Yes & Yes & Unclear & Yes & Yes \\
\hline Cannizzaro 2014 [12] & Yes & Yes & Yes & Yes & Yes & No & Yes \\
\hline Di Renzo 2010 [18] & Unclear & Unclear & Yes & Yes & Yes & Unclear & Yes \\
\hline Docimo 2012 [16] & Unclear & Unclear & Yes & Yes & Yes & Unclear & Yes \\
\hline Duan 2013 [14] & Unclear & Unclear & Yes & Yes & Unclear & Unclear & Yes \\
\hline Ferri 2011 [20] & Yes & Unclear & Yes & Yes & Yes & Unclear & Yes \\
\hline Gentileschi 2011 [21] & Yes & Unclear & Yes & Yes & Unclear & Unclear & Yes \\
\hline Konturek 2012 [9] & Yes & Yes & Yes & Yes & Yes & Unclear & Yes \\
\hline Materazzi 2013 [17] & Yes & Yes & Yes & Yes & Yes & Unclear & Yes \\
\hline Miccoli 2010 [10] & Yes & Yes & Yes & Yes & Unclear & Unclear & Yes \\
\hline Mourad 2011 [22] & Yes & Yes & Yes & Yes & Yes & Yes & Yes \\
\hline Pons 2009 [8] & Yes & Unclear & Yes & Yes & Yes & No & Yes \\
\hline Sista 2012 [13] & Unclear & Unclear & Yes & Yes & Unclear & No & Yes \\
\hline Soroush 2013 [15] & Unclear & Unclear & Yes & Yes & Unclear & Unclear & Yes \\
\hline
\end{tabular}

Yes low risk of bias, No high risk of bias

the Harmonic Focus compared to conventional methods in total thyroidectomy (Fig. 3).

\section{Intra-operative blood loss}

Mean intra-operative blood loss (Harmonic Focus: $29.84 \mathrm{~mL}$, conventional technique: $75.34 \mathrm{~mL}$ ) was statistically significantly reduced by $45.54 \mathrm{~mL}(95 \% \mathrm{CI}:-72.20$ to $-18.89 ; P=0.0008$; 6 studies; $I^{2}=98 \%$ ), a $60.4 \%$ decrease with the Harmonic Focus compared to conventional methods in total thyroidectomy (Fig. 4).

\section{Post-operative pain}

On the basis of three studies comparing the Harmonic Focus to conventional techniques in total thyroidectomy, a statistically significant reduction in mean VAS reported post-operative pain (Harmonic Focus: 2.54, conventional technique: 3.87 ) by 1.33 points ( $95 \% \mathrm{CI}-1.99$ to -0.67 ;
$P<0.0001 ; 3$ studies; $\left.I^{2}=85 \%\right)$ was observed with the Harmonic Focus (Fig. 5).

\section{Length of hospital stay}

Results demonstrated a statistically significant reduction of 0.68 days in the mean postoperative length of hospitalization (Harmonic Focus: 1.89 days, conventional technique: 2.58 days) with the Harmonic Focus (95\% CI: -1.16 to $-0.20 ; P=0.005 ; 9$ studies; $I^{2}=98 \%$ ), a $26.4 \%$ decrease, compared to conventional techniques in total thyroidectomy (Fig. 6).

\section{Drainage volume}

In contrast to conventional methods in total thyroidectomy, mean drainage volume (Harmonic Focus: $16.25 \mathrm{~mL}$, conventional technique: $45.63 \mathrm{~mL}$ ) was statistically significantly

\begin{tabular}{|c|c|c|c|c|c|c|c|c|c|c|c|c|}
\hline \multirow{3}{*}{$\begin{array}{l}\text { Study or Subgroup } \\
\text { Askar } 2011\end{array}$} & \multicolumn{3}{|c|}{ Harmonic Focus } & \multicolumn{3}{|c|}{ Conventional Techniques } & \multirow{3}{*}{$\begin{array}{r}\text { Weight } \\
7.5 \%\end{array}$} & \multirow{2}{*}{$\begin{array}{l}\text { Mean Difference } \\
\text { IV, Random, } 95 \% \text { CI }\end{array}$} & \multirow{2}{*}{\multicolumn{4}{|c|}{$\begin{array}{l}\text { Mean Difference } \\
\text { IV, Random, } 95 \% \mathrm{CI}\end{array}$}} \\
\hline & \multirow{2}{*}{$\begin{array}{l}\text { Mean } \\
50.27\end{array}$} & \multirow{2}{*}{$\begin{array}{r}\text { SD } \\
8.03\end{array}$} & \multirow{2}{*}{$\begin{array}{r}\text { Total } \\
65\end{array}$} & \multirow{2}{*}{$\begin{array}{r}\text { Mean } \\
102.38\end{array}$} & \multirow{2}{*}{$\begin{array}{r}\text { SD } \\
14.63\end{array}$} & \multirow{2}{*}{$\begin{array}{r}\text { Total } \\
65\end{array}$} & & & & & & \\
\hline & & & & & & & & $-52.11[-56.17,-48.05]$ & & - & & \\
\hline Cannizzaro 2014 & 79.36 & 21.88 & 141 & 110 & 25.8 & 124 & $7.3 \%$ & $-30.64[-36.44,-24.84]$ & & $=$ & & \\
\hline Di Renzo 2010 & 62.7 & 14.1 & 31 & 72.7 & 13.6 & 31 & $7.2 \%$ & $-10.00[-16.90,-3.10]$ & & $\rightarrow$ & & \\
\hline Docimo 2012 & 63 & 9 & 100 & 85 & 15 & 100 & $7.5 \%$ & $-22.00[-25.43,-18.57]$ & & $=$ & & \\
\hline Duan 2013 & 79 & 21.5 & 389 & 125 & 30.4 & 389 & $7.5 \%$ & $-46.00[-49.70,-42.30]$ & & $=$ & & \\
\hline Ferri 2011 & 44.9 & 8.3 & 50 & 69.5 & 10.7 & 50 & $7.5 \%$ & $-24.60[-28.35,-20.85]$ & & $=$ & & \\
\hline Gentileschi 2011 & 100 & 34 & 43 & 119 & 30 & 38 & $6.1 \%$ & $-19.00[-32.94,-5.06]$ & & $\longrightarrow$ & & \\
\hline Konturek 2012 & 45.4 & 8.7 & 41 & 64.5 & 14.2 & 41 & $7.4 \%$ & $-19.10[-24.20,-14.00]$ & & $\rightarrow$ & & \\
\hline Materazzi 2013 & 51.9 & 30.3 & 141 & 70.98 & 34.8 & 127 & $7.1 \%$ & $-19.08[-26.93,-11.23]$ & & 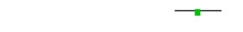 & & \\
\hline Miccoli 2010 & 33.4 & 14.25 & 31 & 47.2 & 8.5 & 31 & $7.3 \%$ & $-13.80[-19.64,-7.96]$ & & $\rightarrow$ & & \\
\hline Mourad 2011 & 57 & 13 & 34 & 80 & 12 & 34 & $7.3 \%$ & $-23.00[-28.95,-17.05]$ & & $\rightarrow$ & & \\
\hline Pons 2009 & 114 & 9 & 20 & 151 & 15 & 20 & $7.1 \%$ & $-37.00[-44.67,-29.33]$ & & 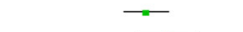 & & \\
\hline Sista 2012 & 91 & 37 & 130 & 121 & 42 & 131 & $6.8 \%$ & $-30.00[-39.60,-20.40]$ & & 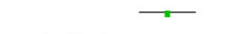 & & \\
\hline Soroush 2013 & 60 & 9.2 & 33 & 121.91 & 30.9 & 35 & $6.6 \%$ & $-61.91[-72.62,-51.20]$ & & & & \\
\hline Total $(95 \% \mathrm{Cl})$ & & & 1249 & & & 1216 & $100.0 \%$ & $-29.13[-36.73,-21.53]$ & & & & \\
\hline $\begin{array}{l}\text { Heterogeneity: } \mathrm{Tau}^{2}= \\
\text { Test for overall effect: }\end{array}$ & $\begin{array}{l}196.95 \\
Z=7.52\end{array}$ & $\begin{array}{l}\mathrm{Chi}^{2}=3 \\
2(\mathrm{P}<0 . \mathrm{C}\end{array}$ & $\begin{array}{l}46.61, d \\
00001)\end{array}$ & $f=13(P<$ & $.00001) ;$ & $96 \%$ & & & -100 & Favours Harmonic Focus & Favours Conv. Techniques & 100 \\
\hline
\end{tabular}




\begin{tabular}{|c|c|c|c|c|c|c|c|c|c|c|c|c|}
\hline \multirow[b]{2}{*}{ Study or Subgroup } & \multicolumn{3}{|c|}{ Harmonic Focus } & \multicolumn{3}{|c|}{ Conventional Techniques } & \multirow[b]{2}{*}{ Weight } & \multirow{2}{*}{$\begin{array}{l}\text { Mean Difference } \\
\text { IV, Random, } 95 \% \mathrm{CI}\end{array}$} & \multirow{2}{*}{\multicolumn{4}{|c|}{$\begin{array}{c}\text { Mean Difference } \\
\text { IV, Random, 95\% Cl }\end{array}$}} \\
\hline & Mean & SD & Total & Mean & SD & Total & & & & & & \\
\hline Askar 2011 & 6.18 & 3 & 65 & 99.07 & 52.5 & 65 & $16.4 \%$ & $-92.89[-105.67,-80.11]$ & & $=$ & & \\
\hline Cannizzaro 2014 & 68.72 & 40.86 & 141 & 97.38 & 35.55 & 124 & $16.7 \%$ & $-28.66[-37.86,-19.46]$ & & $=$ & & \\
\hline Konturek 2012 (1) & 29.9 & 9.8 & 41 & 56.8 & 11 & 41 & $17.0 \%$ & $-26.90[-31.41,-22.39]$ & & $=$ & & \\
\hline Mourad 2011 (2) & 26.4 & 28.3 & 34 & 49.1 & 27.4 & 34 & $16.4 \%$ & $-22.70[-35.94,-9.46]$ & & $=$ & & \\
\hline Pons 2009 & 23 & 19 & 20 & 39 & 19 & 20 & $16.5 \%$ & $-16.00[-27.78,-4.22]$ & & $=$ & & \\
\hline Soroush 2013 & 24.54 & 6.04 & 33 & 110.58 & 19.68 & 35 & $16.9 \%$ & $-86.04[-92.88,-79.20]$ & & 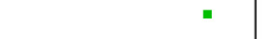 & & \\
\hline Total $(95 \% \mathrm{Cl})$ & & & 334 & & & 319 & $100.0 \%$ & $-45.54[-72.20,-18.89]$ & & - & & \\
\hline \multicolumn{7}{|c|}{$\begin{array}{l}\text { Heterogeneity: } \text { Tau }^{2}=1082.79 ; \mathrm{Chi}^{2}=298.15, \mathrm{df}=5(\mathrm{P}<0.00001) ; \mathrm{I}^{2}=98 \% \\
\text { Test for overall effect: } Z=3.35(\mathrm{P}=0.0008)\end{array}$} & & & -500 & $\begin{array}{c}-250 \\
\text { Favours Harmonic Focus }\end{array}$ & $\begin{array}{c}250 \\
\text { Favours Conv. Techniques }\end{array}$ & $\frac{1}{500}$ \\
\hline
\end{tabular}

reduced by $29.38 \mathrm{~mL}$ (95\% CI: -52.46 to $-6.30 ; P=0.01 ; 3$ studies; $I^{2}=99 \%$ ) with the Harmonic Focus (Fig. 7).

\section{Hemorrhage requiring surgery}

Five of the eight studies examining post-operative bleeding requiring re-operation reported on hemorrhage events. Results demonstrated no statistically significant difference in bleeding events requiring re-operation between the Harmonic Focus and conventional methods $(\mathrm{RR}=0.68$; $95 \%$ CI: 0.19 to $2.46 ; P=0.55 ; 8$ studies; $I^{2}=0 \%$ ) (Fig. 8 ).

\section{Hypocalcemia}

Compared to conventional techniques in total thyroidectomy, the Harmonic Focus resulted in a statistically significant reduction in transient hypocalcemia with a RR of 0.60 (95 \% CI: 0.44 to $0.82 ; P=0.001 ; 12$ studies; $I^{2}=32 \%$ ) (Fig. 9). Persistent hypocalcemia events were reported in only two of the twelve studies examining this outcome. Results demonstrated a lower risk of persistent hypocalcemia with the Harmonic Focus than with conventional methods, although not statistically significant $(\mathrm{RR}=0.35$; $95 \% \mathrm{CI}: 0.07$ to $1.91 ; P=0.23 ; 12$ studies; $\left.I^{2}=0 \%\right)$ (Fig. 10).

\section{RLN paresis}

Harmonic Focus use was associated with fewer transient RLN paresis events compared with conventional thyroidectomy techniques, but these results were not statistically significant $(\mathrm{RR}=0.64 ; 95 \% \mathrm{CI}: 0.28$ to $1.44 ; P=0.28 ; 13$ studies; $I^{2}=0 \%$ ) (Fig. 11). Of the thirteen studies examining persistent RLN paresis, only one study reported an event. In this study, the Harmonic Focus reduced the risk of persistent RLN paresis, although results were not statistically significant $(R R=0.33 ; 95 \% \mathrm{CI}$ : 0.01 to $8.03 ; P=0.50$ ) (Figure not shown).

\section{Wound seroma}

No significant differences were reported between Harmonic Focus and conventional methods for the outcome of wound seroma in total thyroidectomy $(\mathrm{RR}=0.57$; $95 \%$ CI: 0.12 to $2.65 ; P=0.47 ; 2$ studies; $I^{2}=0 \%$ ) (Fig. 12).

\section{Sensitivity analyses}

Sensitivity analyses demonstrated results similar to the primary analysis and were relatively robust to variables tested. Results for operating time, intraoperative blood loss, post-operative pain, length of hospitalization and transient hypocalcemia remained statistically significantly lower with the Harmonic Focus when studies with a higher risk of bias were excluded (Table 4). Additionally, primary analysis results were relatively robust to the exclusion of studies with conventional techniques that did not utilize monopolar or bipolar electrocautery or when imputed results by Miccoli et al. [10] were excluded for operating time.

\section{Discussion}

Although thyroidectomy was not one of the initial applications of ultrasonic surgery, it was realized that use of the Harmonic scalpel provides many advantages over the conventional procedures. Because of the high vascularization of the thyroid gland, efficient and meticulous hemostasis is required to reduce the risk of complications and postoperative morbidity. As with any surgical procedure, a reduction in operative time will typically lessen the chance of surgical-site infection and may lead to faster patient

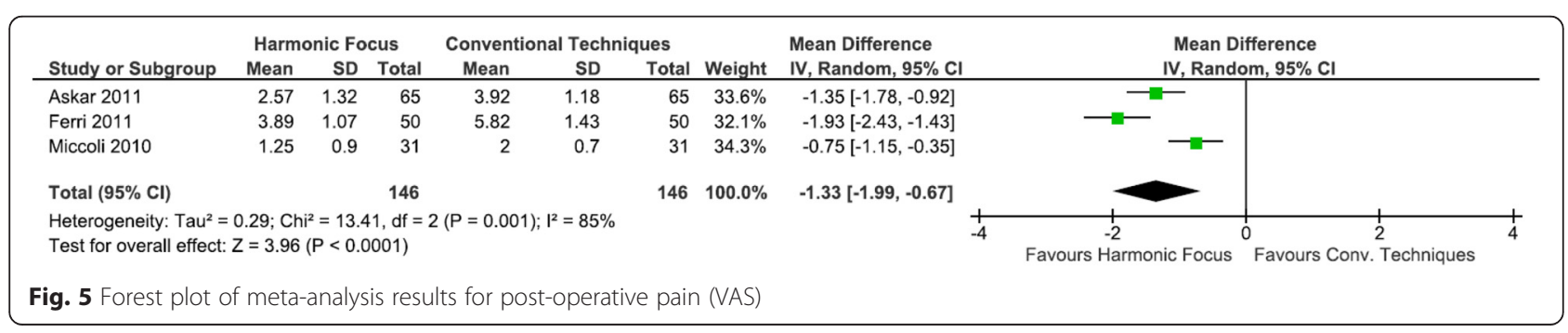




\begin{tabular}{|c|c|c|c|c|c|c|c|c|c|c|}
\hline \multirow{4}{*}{ Study or Subgroup } & \multicolumn{3}{|c|}{ Harmonic Focus } & \multicolumn{3}{|c|}{ Conventional Techniques } & \multirow[b]{2}{*}{ Weight } & \multirow{2}{*}{$\begin{array}{l}\text { Mean Difference } \\
\text { IV, Random, } 95 \% \mathrm{CI}\end{array}$} & \multirow{2}{*}{\multicolumn{2}{|c|}{$\begin{array}{c}\text { Mean Difference } \\
\text { IV, Random, } 95 \% \mathrm{Cl}\end{array}$}} \\
\hline & Mean & SD & Total & Mean & SD & Total & & & & \\
\hline & 0.66 & 0.25 & 65 & 1.98 & 0.97 & 65 & $11.4 \%$ & $-1.32[-1.56,-1.08]$ & 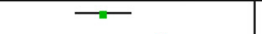 & \\
\hline & 1.93 & 0.496 & 141 & 2.75 & 0.739 & 124 & $11.6 \%$ & $-0.82[-0.97,-0.67]$ & - & \\
\hline Di Renzo 2010 & 2.2 & 0.3 & 31 & 2.3 & 0.6 & 31 & $11.4 \%$ & $-0.10[-0.34,0.14]$ & . & \\
\hline Duan 2013 & 2.9 & 1 & 389 & 2.6 & 0.9 & 389 & $11.6 \%$ & $0.30[0.17,0.43]$ & & $=$ \\
\hline Ferri 2011 & 2.2 & 0.9 & 50 & 3.7 & 1.3 & 50 & $10.7 \%$ & $-1.50[-1.94,-1.06]$ & & \\
\hline Gentileschi 2011 & 2.8 & 1 & 43 & 2.9 & 2 & 38 & $9.3 \%$ & $-0.10[-0.80,0.60]$ & & \\
\hline Konturek 2012 & 1.3 & 0.5 & 41 & 1.4 & 0.6 & 41 & $11.4 \%$ & $-0.10[-0.34,0.14]$ & - & - \\
\hline Materazzi 2013 & 2.02 & 0.9 & 141 & 3.1 & 1.1 & 127 & $11.4 \%$ & $-1.08[-1.32,-0.84]$ & & \\
\hline Soroush 2013 & 1.15 & 0.36 & 33 & 2.54 & 0.56 & 35 & $11.4 \%$ & $-1.39[-1.61,-1.17]$ & $\longrightarrow$ & \\
\hline Total $(95 \% \mathrm{Cl})$ & & & 934 & & & 900 & $100.0 \%$ & $-0.68[-1.16,-0.20]$ & & \\
\hline \multicolumn{9}{|c|}{$\begin{array}{l}\text { Heterogeneity: } \mathrm{Tau}^{2}=0.51 ; \mathrm{Chi}^{2}=324.26 \text {, df } \\
\text { Test for overall effect: } Z=2.80(P=0.005)\end{array}$} & $\begin{array}{l}-2 \\
\text { Favours Harmonic Focus }\end{array}$ & $\begin{array}{ccc}0 & 1 & 2 \\
\text { Favours Conv. Techniques }\end{array}$ \\
\hline
\end{tabular}

recovery time [23]. Rapid coagulation with the Harmonic Focus can substantially increase the speed of the operation. In addition, the precision of the Harmonic Focus can ensure that the risk of the two principal adverse events, namely hypocalcemia and recurrent laryngeal nerve paresis, are not elevated, or may even be reduced.

Five standard meta-analyses have compared ultrasonic devices to conventional techniques in thyroidectomy. These previous findings are in general similar to those in this study. In analyzing 9 studies, Melck [24] observed significantly faster operative time $(-23.1 \mathrm{~min}, p<0.001)$, and less transient hypocalcemia (RR 0.69, $p=0.01$ ) for use of ultrasonic devices compared to conventional methods. In 7 studies, Cirocchi [25] found significantly faster operative time $(-18.7 \mathrm{~min}, p<0.001)$, less blood loss $(-60.1 \mathrm{ml}, p=0.04)$, and less drainage volume $(-35.3 \mathrm{ml}, p<0.001)$. In 11 studies, Zhang [26] found significantly faster operative time $(-22.4 \mathrm{~min}, p<0.001)$, and less intraoperative bleeding $(-26.6 \mathrm{ml}, p=0.02)$. In 12 studies, Ecker [27] observed significantly faster operative time ( $-22.7 \mathrm{~min}, p<0.001)$, less blood loss $(-20.0 \mathrm{ml}, p<0.001)$, less post-operative pain (-0.86 units, $p=0.02)$, and reduced length of hospital stay ( -0.12 days, $p=0.05)$. Finally, in 13 studies, Zhao [28] found significantly faster operative time (-21.1 $\mathrm{min}, \quad p<0.001)$, less intra-operative blood loss $(-14.4 \mathrm{ml}, p<0.001)$, less drainage $(-7.5 \mathrm{ml}, p<0.001)$, and lower hospitalization charges $(-118$ USD, $p<0.001)$. None of these meta-analyses found a higher rate of transient or persistent RLN paresis for ultrasonic devices compared to conventional techniques.
Recently two network meta-analyses have been performed. In these studies, ultrasonic devices were compared to both conventional techniques and advanced bipolar technology. In one of these network metaanalyses, Contin [7] evaluated 21 studies and found significantly faster operative time $(-22.3 \mathrm{~min}, p<0.001)$, less intraoperative blood loss $(-28.5 \mathrm{ml}, p<0.001)$, shorter hospital stay $(-0.28$ days, $p=0.016)$ and less postoperative bleeding $(-11.2 \mathrm{ml}, p<0.001)$ for ultrasonic devices. There was a trend toward lower transient hypocalcemia $(p=0.066)$ for ultrasonic, and importantly no difference in rates of transient RLN paresis $(p=0.847)$ or persistent RLN paresis $(p=0.711)$. Interestingly, the mean difference of operative time for investigator-initiated trials was greater than for industry-sponsored trials, belying the notion in this case that industry trials are necessarily biased toward their own commercial product.

In the other network meta-analysis, Garas [29] claimed to use 25 RCT's, although one of the studies misidentified an electrosurgical device as ultrasonic and another study was not randomized [7, 30]. In comparing ultrasonic to conventional, they reported significantly faster operative time $(p<0.01)$, less blood loss $(p<0.01)$, less drain output $(p=0.03)$, and lower cost $(p=0.03)$, but a trend towards higher persistent RLN paresis $(p=0.08)$ for ultrasonic. A re-tabulation of the studies included in the Garas analysis [30] indicated 1/1006 (0.1\%) cases of persistent RLN paresis for ultrasonic versus 2/992 $(0.2 \%)$ for conventional surgery. In the current work, which included only studies where Harmonic Focus was

\begin{tabular}{|c|c|c|c|c|c|c|c|c|c|c|c|c|}
\hline Study or Subgroup & \multicolumn{3}{|c|}{ Harmonic Focus } & \multicolumn{3}{|c|}{ Conventional Techniques } & Weight & $\begin{array}{l}\text { Mean Difference } \\
\text { IV, Random, } 95 \% \mathrm{Cl}\end{array}$ & \multicolumn{4}{|c|}{$\begin{array}{c}\text { Mean Difference } \\
\text { IV, Random, } 95 \% \mathrm{Cl}\end{array}$} \\
\hline Askar 2011 & 5.6 & 3.48 & 65 & 68.07 & 23.26 & 65 & $33.0 \%$ & $-62.47[-68.19,-56.75]$ & & $\overline{2}$ & & \\
\hline Ferri 2011 & 37.4 & 2.4 & 50 & 56.1 & 4.2 & 50 & $33.7 \%$ & $-18.70[-20.04,-17.36]$ & & घ & & \\
\hline Miccoli 2010 & 5.41 & 6.5 & 31 & 12.8 & 9.94 & 31 & $33.3 \%$ & $-7.39[-11.57,-3.21]$ & & - & & \\
\hline Total $(95 \% \mathrm{Cl})$ & & & 146 & & & 146 & $100.0 \%$ & $-29.38[-52.46,-6.30]$ & & & & \\
\hline $\begin{array}{l}\text { Heterogeneity: } \mathrm{Tau}^{2}= \\
\text { Test for overall effect: }\end{array}$ & $\begin{array}{l}411.59 \\
Z=2.49\end{array}$ & $\begin{array}{l}\mathrm{hi}^{2}=2 \\
\mathrm{P}=0.0\end{array}$ & $50.39, \mathrm{~d}$ & $f=2(P<0$ & 001); $1^{2}$ & $9 \%$ & & & -200 & Favours $\begin{array}{c}-100 \\
\text { Harmonic Focus }\end{array}$ & Favours Conv. Techniques & $\frac{1}{200}$ \\
\hline
\end{tabular}




\begin{tabular}{|c|c|c|c|c|c|c|c|c|c|c|}
\hline \multirow[b]{2}{*}{ Study or Subgroup } & \multicolumn{2}{|c|}{ Harmonic Focus } & \multicolumn{2}{|c|}{ Conventional Techniques } & \multirow[b]{2}{*}{ Weight } & \multirow{2}{*}{$\begin{array}{l}\text { Risk Ratio } \\
\text { M-H, Random, } 95 \% \mathrm{Cl}\end{array}$} & \multirow{2}{*}{\multicolumn{4}{|c|}{$\begin{array}{c}\text { Risk Ratio } \\
\mathrm{M}-\mathrm{H}, \text { Random, } 95 \% \mathrm{Cl}\end{array}$}} \\
\hline & Events & Total & Events & Total & & & & & & \\
\hline Askar 2011 & 0 & 65 & 1 & 65 & $16.4 \%$ & $0.33[0.01,8.03]$ & & & & \\
\hline Di Renzo 2010 & 0 & 31 & 0 & 31 & & Not estimable & & & & \\
\hline Docimo 2012 & 1 & 100 & 1 & 100 & $21.8 \%$ & $1.00[0.06,15.77]$ & & & & \\
\hline Duan 2013 & 0 & 389 & 1 & 389 & $16.2 \%$ & $0.33[0.01,8.16]$ & & & & \\
\hline Gentileschi 2011 & 0 & 43 & 1 & 38 & $16.5 \%$ & $0.30[0.01,7.04]$ & & & & \\
\hline Konturek 2012 & 0 & 41 & 0 & 41 & & Not estimable & & & & \\
\hline Materazzi 2013 & 2 & 141 & 1 & 127 & $29.1 \%$ & $1.80[0.17,19.63]$ & & & 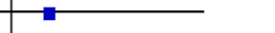 & \\
\hline Pons 2009 & 0 & 20 & 0 & 20 & & Not estimable & & & & \\
\hline Total $(95 \% \mathrm{Cl})$ & & 830 & & 811 & $100.0 \%$ & $0.68[0.19,2.46]$ & & & & \\
\hline Total events & 3 & & 5 & & & & & & & \\
\hline \multicolumn{2}{|c|}{ Test for overall effect: $Z=0.59(P=0.55)$} & & & & & & 0.01 & $\begin{array}{l}0.1 \\
\text { Favours Harmonic Focus }\end{array}$ & ${ }^{1}$ Favours Conv. Techniques & 100 \\
\hline
\end{tabular}

used, there was no difference in the rate of persistent RLN paresis $(p=0.50)$, with zero cases among a total of 1119 subjects for Harmonic $(0.0 \%)$ and one case among 1085 subjects for conventional techniques $(0.1 \%)$. This lack of difference was also confirmed in the Contin network meta-analysis [7], which suggested that the results of Garas "should be read with caution." Based on the results of the standard and network meta-analyses, including re-analysis of the Garas study, and the current study, all of which show no difference between ultrasonic devices and conventional techniques, there should be high confidence that Harmonic Focus can be used thyroidectomy with a low risk of RLN paresis, equivalent to conventional clamp, cut and tie.

In contrast to all previous efforts, the current study was limited to only Harmonic Focus as the ultrasonic device of interest. The Harmonic Focus is designed for use in open procedures and is specifically cleared for applications in head and neck surgery. A small end effector enables precise placement and the ultrasonic energy provides rapid dissection and coagulation. As evidenced in all studies to date, the design of the Harmonic Focus gives substantial advantages over conventional techniques in thyroidectomy.

In the current study, we observed operative time was significantly faster for Harmonic Focus compared to conventional clamp, cut, and tie. This speed increase is a result of both faster dissection and better hemostasis. Shorter operative time can lead to improved patient outcomes and faster recovery, and provide operative and overall hospital cost savings $[8,9]$. The difference of 29 min observed in this study represents a $31 \%$ decrease in operative time compared to conventional technique. Other measures related to the hemostasis capabilities are intra-operative blood loss and drainage volume, where use of Focus led to decreases of $60 \%$ and $64 \%$, respectively, compared to clamp, cut and tie.

Post-operative pain was $34 \%$ lower for Harmonic Focus than clamp, cut, and tie. This advantage may be related to shorter operative time noted above and observations that ultrasonic devices generally cause less inflammation [31-33]. The decrease of 1.33 points represents a $34 \%$ reduction in pain compared to conventional surgery. The decrease in length of hospital

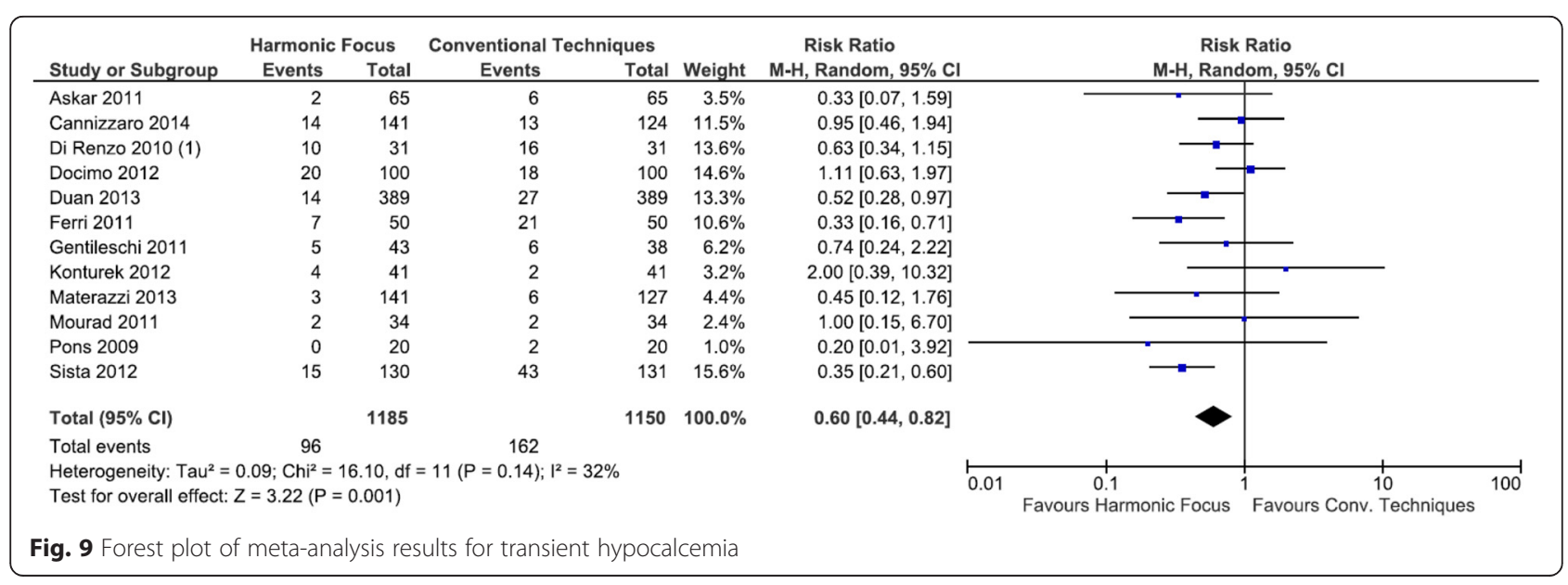




\begin{tabular}{|c|c|c|c|c|c|c|c|c|c|c|}
\hline \multirow[b]{2}{*}{ Study or Subgroup } & \multicolumn{2}{|c|}{ Harmonic Focus } & \multicolumn{2}{|c|}{ Conventional Techniques } & \multirow[b]{2}{*}{ Weight } & \multirow{2}{*}{$\begin{array}{c}\text { Risk Ratio } \\
\text { M-H, Random, } 95 \% \mathrm{Cl}\end{array}$} & \multirow{2}{*}{\multicolumn{4}{|c|}{$\begin{array}{c}\text { Risk Ratio } \\
\text { M-H, Random, } 95 \% \mathrm{Cl}\end{array}$}} \\
\hline & Events & Total & Events & Total & & & & & & \\
\hline Askar 2011 & 0 & 65 & 0 & 65 & & Not estimable & & & & \\
\hline Cannizzaro 2014 & 0 & 141 & 0 & 124 & & Not estimable & & & & \\
\hline Di Renzo 2010 & 0 & 31 & 0 & 31 & & Not estimable & & & & \\
\hline Docimo 2012 & 0 & 100 & 0 & 100 & & Not estimable & & & & \\
\hline Duan 2013 & 0 & 389 & 0 & 389 & & Not estimable & & & & \\
\hline Ferri 2011 & 0 & 50 & 0 & 50 & & Not estimable & & & & \\
\hline Gentileschi 2011 & 0 & 43 & 0 & 38 & & Not estimable & & & & \\
\hline Konturek 2012 & 0 & 41 & 0 & 41 & & Not estimable & & & & \\
\hline Materazzi 2013 & 1 & 141 & 1 & 127 & $37.4 \%$ & $0.90[0.06,14.25]$ & & & & \\
\hline Mourad 2011 & 0 & 34 & 0 & 34 & & Not estimable & & & & \\
\hline Pons 2009 & 0 & 20 & 0 & 20 & & Not estimable & & & & \\
\hline Sista 2012 & 1 & 130 & 5 & 131 & $62.6 \%$ & $0.20[0.02,1.70]$ & & - & & \\
\hline Total $(95 \% \mathrm{Cl})$ & & 1185 & & 1150 & $100.0 \%$ & $0.35[0.07,1.91]$ & & & & \\
\hline Total events & 2 & & 6 & & & & & & & \\
\hline \multicolumn{2}{|c|}{ Test for overall effect: $Z=1.21(P=0.23)$} & & & & & & 0.01 & $\begin{array}{c}0.1 \\
\text { Favours Harmonic Focus }\end{array}$ & $\begin{array}{c}10 \\
10 \\
\text { Favours Conv. Techniques }\end{array}$ & 100 \\
\hline
\end{tabular}

stay, a $26 \%$ reduction relative to conventional procedures, may be related to shorter operative time, lessened blood loss and drainage and less post-operative pain.

For the dichotomous results evaluated, namely, hemorrhage requiring surgery, hypocalcemia, RLN paresis, and wound seroma, all were less frequent with Harmonic than conventional technique, but because of the low frequency of all these events, only for transient hypocalcemia was there a significant difference, with Harmonic having a $40 \%$ lower rate of occurrence than conventional clamp, cut, and tie. This significantly lower rate of transient hypocalcemia may be a result of the shorter operative time and reduced overall systemic impact of surgery with Harmonic Focus compared to conventional surgery. A drop in calcium blood levels may result not just from unintended damage to the parathyroid gland by clamp, cut and tie, but also be a typical systemic response to longer, more involved surgical procedures. While Harmonic Focus provides a lower rate of transient hypocalcemia, there does not appear to be a long-term difference, as the rate of persistent hypocalcemia is not significantly different from conventional procedures.

As demonstrated in this and all other reliable metaanalyses, the rate of both transient and persistent RLN paresis with ultrasonic devices is not greater than with clamp, cut \& tie procedures. In fact, the trend with Harmonic Focus suggests that with more data it may be possible to show a reduction in transient RLN paresis. The cause of transient RLN paresis is generally assigned to excess traction. Use of continuous intra-operative nerve monitoring with stimulation to the vagus nerve can avoid paresis if the traction is reduced when the electromyographic reading has decreased by $50 \%$ or more [34]. The improved dissecting ability of ultrasonic devices may decrease the amount of traction compared to clamp, cut and tie. The etiology of persistent paresis is typically prolonged thermal, electrical or direct contact with transection of the RLN. To avoid this complication, it is critical to visually identify the RLN during

\begin{tabular}{|c|c|c|c|c|c|c|c|c|c|c|}
\hline \multirow[b]{2}{*}{ Study or Subgroup } & \multicolumn{2}{|c|}{ Harmonic Focus } & \multicolumn{2}{|c|}{ Conventional Techniques } & \multirow[b]{2}{*}{ Weight } & \multirow{2}{*}{$\begin{array}{c}\text { Risk Ratio } \\
\text { M-H, Random, } 95 \% \text { CI }\end{array}$} & \multirow{2}{*}{\multicolumn{4}{|c|}{$\begin{array}{c}\text { Risk Ratio } \\
\text { M-H, Random, } 95 \% \mathrm{Cl} \\
\end{array}$}} \\
\hline & Events & Total & Events & Total & & & & & & \\
\hline Askar 2011 & 2 & 65 & 5 & 65 & $25.5 \%$ & $0.40[0.08,1.99]$ & & & & \\
\hline Cannizzaro 2014 & 1 & 141 & 1 & 124 & $8.6 \%$ & $0.88[0.06,13.91]$ & & & & \\
\hline Di Renzo 2010 & 1 & 31 & 0 & 31 & $6.6 \%$ & $3.00[0.13,70.92]$ & & & & \\
\hline Docimo 2012 & 1 & 100 & 1 & 100 & $8.6 \%$ & $1.00[0.06,15.77]$ & & & & \\
\hline Duan 2013 & 0 & 389 & 1 & 389 & $6.4 \%$ & $0.33[0.01,8.16]$ & & & & \\
\hline Ferri 2011 & 0 & 50 & 2 & 50 & $7.2 \%$ & $0.20[0.01,4.06]$ & & & & \\
\hline Gentileschi 2011 & 0 & 43 & 1 & 38 & $6.5 \%$ & $0.30[0.01,7.04]$ & & & & \\
\hline Konturek 2012 & 1 & 41 & 1 & 41 & $8.8 \%$ & $1.00[0.06,15.45]$ & & & & \\
\hline Materazzi 2013 & 1 & 141 & 1 & 127 & $8.6 \%$ & $0.90[0.06,14.25]$ & & & & \\
\hline Miccoli 2010 & 0 & 31 & 0 & 31 & & Not estimable & & & & \\
\hline Mourad 2011 & 0 & 34 & 1 & 34 & $6.5 \%$ & $0.33[0.01,7.91]$ & & & & \\
\hline Pons 2009 & 1 & 20 & 0 & 20 & $6.6 \%$ & $3.00[0.13,69.52]$ & & & & \\
\hline Soroush 2013 & 0 & 33 & 0 & 35 & & Not estimable & & & & \\
\hline Total $(95 \% \mathrm{Cl})$ & & 1119 & & 1085 & $100.0 \%$ & $0.64[0.28,1.44]$ & & & & \\
\hline Total events & 8 & & 14 & & & & & & & \\
\hline \multicolumn{7}{|c|}{ Test for overall effect: $Z=1.08(P=0.28)$} & $\stackrel{\vdash}{\circ .01}$ & $\begin{array}{c}1 \\
0.1 \\
\text { Favours Harmonic Focus }\end{array}$ & $\begin{array}{cc} & 1 \\
10 & 10 \\
\text { Favours Conv. Techniques }\end{array}$ & $\overrightarrow{100}$ \\
\hline
\end{tabular}




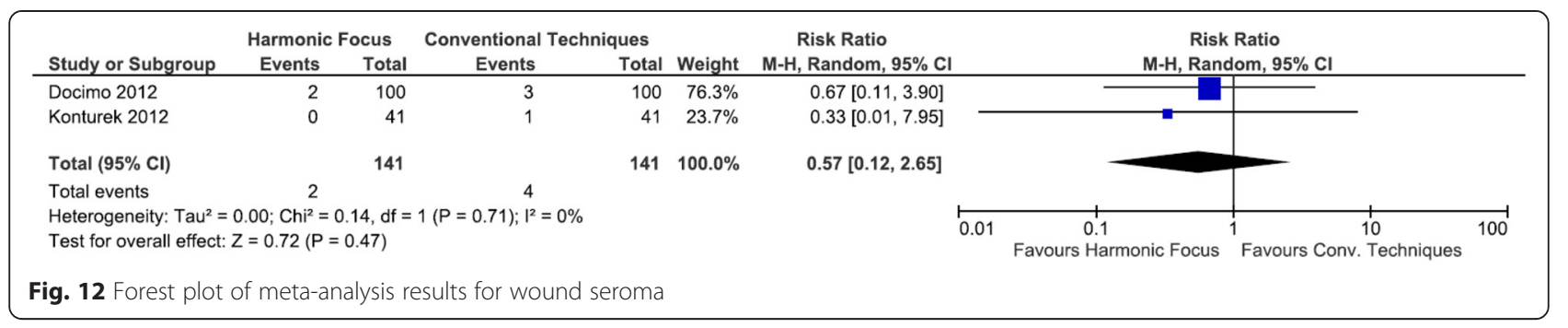

Table 4 Summary of primary and sensitivity analyses

\begin{tabular}{|c|c|c|c|c|}
\hline \multirow[t]{2}{*}{ Outcome } & \multirow[t]{2}{*}{ Primary analysis } & \multicolumn{3}{|l|}{ Sensitivity analyses } \\
\hline & & $\begin{array}{l}\text { Excluding 'lower' quality } \\
\text { studies }[8,12-15]^{a}\end{array}$ & $\begin{array}{l}\text { Excluding imputed data } \\
{[10]^{b}}\end{array}$ & $\begin{array}{l}\text { Excluding studies that did not } \\
\text { use electrocautery in conventional }[8,15-18]\end{array}$ \\
\hline $\begin{array}{l}\text { Operating Time } \\
\text { (min) }\end{array}$ & $-29.13(-36.73,-21.53)$ & $-22.72(-31.75,-13.68)$ & $-30.34(-38.13,-22.54)$ & $-28.95(-38.44,-19.35)$ \\
\hline \multicolumn{5}{|l|}{$(\mathrm{MD}[95 \% \mathrm{Cl}])$} \\
\hline $\begin{array}{l}\text { Intraoperative } \\
\text { Blood Loss (mL) }\end{array}$ & $-45.54(-72.20,-18.89)$ & $-42.48(-67.97,-16.99)$ & $\begin{array}{l}\text { Identical to primary } \\
\text { analysis }\end{array}$ & $-42.48(-67.97,-16.99)$ \\
\hline \multicolumn{5}{|l|}{ (MD [95\%Cl]) } \\
\hline $\begin{array}{l}\text { Post-Operative } \\
\text { Pain (VAS) }\end{array}$ & $-1.33(-1.99,-0.67)$ & $-1.33(-1.99,-0.67)$ & & $-1.33(-1.99,-0.67)$ \\
\hline \multicolumn{5}{|l|}{ (MD [95\%Cl]) } \\
\hline $\begin{array}{l}\text { Length of Stay } \\
\text { (days) }\end{array}$ & $-0.68(-1.16,-0.20)$ & $-0.71(-1.24,-0.18)$ & & $-0.59(-1.21,0.02)$ \\
\hline \multicolumn{5}{|l|}{ (MD [95 \%Cl]) } \\
\hline $\begin{array}{l}\text { Drainage Volume } \\
(\mathrm{mL})\end{array}$ & $-29.38(-52.46,-6.30)$ & $-29.38(-52.46,-6.30)$ & & $-29.38(-52.46,-6.30)$ \\
\hline \multicolumn{5}{|l|}{ (MD [95\%Cl]) } \\
\hline $\begin{array}{l}\text { Hemorrhage } \\
\text { require surgery }\end{array}$ & $0.68(0.19,2.46)$ & $0.78(0.19,3.18)$ & & $0.32(0.05,2.01)$ \\
\hline \multicolumn{5}{|l|}{ (RR $[95 \%$ CI]) } \\
\hline $\begin{array}{l}\text { Transient } \\
\text { Hypocalcemia }\end{array}$ & $0.60(0.44,0.82)$ & $0.67(0.45,1.00)$ & & $0.54(0.37,0.78)$ \\
\hline \multicolumn{5}{|l|}{ (RR $[95 \% C I])$} \\
\hline $\begin{array}{l}\text { Persistent } \\
\text { Hypocalcemia }\end{array}$ & $0.35(0.07,1.91)$ & $0.90(0.06,14.25)$ & & Too few studies to inform $(<2)$ \\
\hline \multicolumn{5}{|l|}{ (RR $[95 \% \mathrm{Cl}])$} \\
\hline $\begin{array}{l}\text { Transient RLN } \\
\text { Paresis }\end{array}$ & $0.64(0.28,1.44)$ & $0.57(0.23,1.43)$ & & $0.43(0.16,1.14)$ \\
\hline \multicolumn{5}{|l|}{ (RR $[95 \% \mathrm{Cl}])$} \\
\hline $\begin{array}{l}\text { Persistent RLN } \\
\text { Paresis }\end{array}$ & $0.33(0.01,8.03)$ & $0.33(0.01,8.03)$ & & Too few studies to inform $(<2)$ \\
\hline \multicolumn{5}{|l|}{ (RR $[95 \% \mathrm{Cl}])$} \\
\hline Wound Seroma & $0.57(0.12,2.65)$ & $0.57(0.12,2.65)$ & & Too few studies to inform $(<2)$ \\
\hline (RR $[95 \% C l])$ & & & & \\
\hline
\end{tabular}

Cl Confidence Interval, LOS Length of Stay, MD Mean Difference, RR Relative Risk, VAS Visual Analog Scale, min minutes, $m L$ milliliters

aLower quality study defined as: $\geq 4$ "unclear" OR one "No" listed in any risk of bias assessment category: Cannizzaro [12], Pons [8], Sista [13], Duan [14],

Soroush [15]

${ }^{\mathrm{b}}$ Miccoli [10]

'Di Renzo [14], Docimo [16], Materazzi [17], Pons [8], Soroush [15] 
surgery. Use of an ultrasonic device eliminates electrical current and gives a wider margin of error for thermal effects compared to monopolar electrosurgery.

Numerous preclinical studies have evaluated the impact of Harmonic technology when used close to a nerve [32]. All studies to date have shown an effect on nerve function similar to that of cold steel scalpel when used up to $2 \mathrm{~mm}$ from the nerve. Important caveats to remember are that activation time should be less than $15 \mathrm{~s}$ and the nerve itself should never be touched directly either during activation or immediately afterwards. As all energy technologies generate heat, they must be carefully managed. In contrast to ultrasonic energy, monopolar and bipolar technologies produce at minimum transient injury when used up to $5 \mathrm{~mm}$ from the nerve. Recently, the potential adverse effects of advanced bipolar technologies were demonstrated with a doubling of $\beta$ amyloid precursor protein, a marker of impaired axonal transport, and a $133 \%$ increase in neural inflammation when compared to ultrasonic energy [35].

Despite the comfort that can be developed from studies evaluating Focus, it must be stressed that no technology will replace meticulous surgical techniques and no technology is fool-proof. In that regard, the important elements must always be kept foremost in the surgeon's mind when using Harmonic Focus. First, activations should occur as far from nerves or glands as possible, and no closer than $2 \mathrm{~mm}$. Second, continuous activation should be less than $15 \mathrm{~s}$ as one approaches the nerve. Finally, the heat of the instrument must be actively managed by cooling, and an activated instrument should never touch the nerve during dissection.

\section{Conclusions}

The Harmonic Focus is a more effective surgical device compared to conventional techniques in thyroidectomy. Its use offers several clinical advantages, including reduced operating time, intra-operative blood loss, drainage volume, post-operative pain, length of hospital stay, and transient hypocalcemia which can ultimately benefit the surgeon, patient and hospital, without the addition of safety concerns.

All studies performed to-date have used Harmonic Focus, prior to the introduction of an improved version, Harmonic Focus+, which has a substantially smaller end effector and produces a significantly smaller thermal effect [35]. All of the benefits observed in this study are expected to be maintained or even improved upon with the increased precision of the new device.

\section{Competing interests}

HC, JWC, and JFA are employees of Ethicon, Inc., manufacturer of the Harmonic Focus. IS and NCF are employees of Cornerstone Research Group, who were sponsored to perform this study by Ethicon, Inc.

\section{Funding}

This work was supported by Ethicon, Inc., manufacturer of the Harmonic Focus, who provided funding to conduct the analysis and prepare the manuscript.

\section{Author details}

${ }^{1}$ Ethicon Inc, 4545 Creek Rd, Cincinnati, OH 45242, USA. ${ }^{2}$ Cornerstone Research Group, 204-3228 South Service Road, Burlington, ON L7N 3H8, Canada.

Received: 8 September 2015 Accepted: 21 September 2015

Published online: 01 October 2015

\section{References}

1. Amaral JF. The experimental development of an ultrasonically activated scalpel for laparoscopic use. Surg Laparosc Endosc. 1994;4(2):92-9.

2. Amaral JF. Laparoscopic cholecystectomy in 200 consecutive patients using an ultrasonically activated scalpel. Surg Laparosc Endosc. 1995;5(4):255-62.

3. Heimann TM, Kurtz RJ, Shen S, Aufses Jr AH. Mucosal proctectomy using an ultrasonic scalpel. Am J Surg. 1984;147(6):803-6.

4. Soares RS, Amaral JF. Laparoscopic nissen fundoplication using ultrasonic cutting and coagulation. Surg Technol Int. 1998;7:119-23.

5. Robbins ML, Ferland RJ. Laparoscopic-assisted vaginal hysterectomy using the laparosonic coagulating shears. J Am Assoc Gynecol Laparosc. 1995;2(3):339-43.

6. Miccoli P, Berti P, Raffaelli M, Materazzi G, Conte M, Galleri D. Impact of harmonic scalpel on operative time during video-assisted thyroidectomy. Surg Endosc. 2002;16(4):663-6.

7. Contin P, Goossen K, Grummich K, Jensen K, Schmitz-Winnenthal H, Buchler MW, et al. ENERgized vessel sealing systems versus CONventional hemostasis techniques in thyroid surgery-the ENERCON systematic review and network meta-analysis. Langenbecks Arch Surg. 2013;398(8):1039-56.

8. Pons Y, Gauthier J, Ukkola-Pons E, Clement P, Roguet E, Poncet JL, et al. Comparison of LigaSure vessel sealing system, harmonic scalpel, and conventional hemostasis in total thyroidectomy. Otolaryngol Head Neck Surg. 2009;141(4):496-501.

9. Konturek A, Barczynski M, Stopa M, Nowak W. Total thyroidectomy for nontoxic multinodular goiter with versus without the use of harmonic FOCUS dissecting shears - a prospective randomized study. Wideochir Inne Tech Maloinwazyjne. 2012;7(4):268-74.

10. Miccoli P, Materazzi G, Miccoli M, Frustaci G, Fosso A, Berti P. Evaluation of a new ultrasonic device in thyroid surgery: comparative randomized study. Am J Surg. 2010;199(6):736-40.

11. Higgins J, Green S. The Cochrane handbook for systematic reviews of interventions. 2011. http://handbook.cochrane.org/ Accessed August 13, 2015.

12. Cannizzaro MA, Bianco SL, Borzi L, Cavallaro A, Buffone A. The use of FOCUS Harmonic scalpel compared to conventional haemostasis (knot and tie ligation) for thyroid surgery: a prospective randomized study. SpringerPlus. 2014;3:639.

13. Sista F, Schietroma M, Ruscitti C, De Santis G, De Vita F, Carlei F, et al. New ultrasonic dissector versus conventional hemostasis in thyroid surgery: a randomized prospective study. J Laparoendosc Adv Surg Tech A. 2012;22(3):220-4.

14. Duan YF, Xue W, Zhu F, Sun DL. FOCUS harmonic scalpel compared to conventional hemostasis in open total thyroidectomy - a prospective randomized study. J Otolaryngol Head Neck Surg. 2013;42:62.

15. Soroush A, Pourbakhtyaran E, Allame S, Zamani MM, Etemadi M, Nasiri S. Harmonic scalpel is more secure than conventional methods in total thyroidectomy: a randomized clinical trial. J Minim Invasive Surg Sci. 2013;2(3):23-7.

16. Docimo G, Ruggiero R, Gubitosi A, Casalino G, Bosco A, Gili S, et al. Ultrasound scalpel in thyroidectomy. Prospective randomized study. Ann Ital Chir. 2012;83(6):491-6.

17. Materazzi G, Caravaglios G, Matteucci V, Aghababyan A, Miccoli M, Miccoli P. The impact of the Harmonic FOCUS on complications in thyroid surgery: a prospective multicenter study. Updat Surg. 2013;65(4):295-9.

18. Di Renzo RM, Bove A, Bongarzoni G, Palone G, Corradetti L, Corbellini L. Comparison of conventional technique, Ligasure Precise and Harmonic Focus in total thyroidectomy. G Chir. 2010;31(6-7):296-8. 
19. Askar W, Roshdy H, El Nakeeb A, Moatamed A, El Lithy R, Hayes S. The use of harmonic scalpel versus knot tying for total-thyroidectomy. A prospective randomized study. Egypt J Surg. 2011;30(2):48-54.

20. Ferri E, Armato $E$, Spinato G, Spinato R. Focus harmonic scalpel compared to conventional haemostasis in open total thyroidectomy: a prospective randomized trial. Int J Otolaryngol. 2011;2011:357195.

21. Gentileschi P, D'Ugo S, laculli E, Gaspari AL. Harmonic Focus versus "knot tying" during total thyroidectomy: a randomized trial. Updat Surg. 2011;63(4):277-81.

22. Mourad M, Rulli F, Robert A, Scholtes JL, De Meyer M, De Pauw L. Randomized clinical trial on Harmonic Focus shears versus clamp-and-tie technique for total thyroidectomy. Am J Surg. 2011;202(2):168-74.

23. Elfenbein DM, Schneider DF, Chen H, Sippel RS. Surgical site infection after thyroidectomy: a rare but significant complication. J Surg Res. 2014;190(1):170-6.

24. Melck AL, Wiseman SM. Harmonic scalpel compared to conventional hemostasis in thyroid surgery: a meta-analysis of randomized clinical trials. Int J Surg Oncol. 2010;2010:396079.

25. Cirocchi R, D'Ajello F, Trastulli S, Santoro A, Di Rocco G, Vendettuoli D, et a Meta-analysis of thyroidectomy with ultrasonic dissector versus conventional clamp and tie. World J Surg Oncol. 2010;8:112.

26. Zhang ZJ, Zhang P, Tian JH, Li J, Li L, Tian J, et al. Ultrasonic coagulator for thyroidectomy: a systematic review of randomized controlled trials. Surg Innov. 2010;17(1):41-7.

27. Ecker T, Carvalho AL, Choe JH, Walosek G, Preuss KJ. Hemostasis in thyroid surgery: harmonic scalpel versus other techniques-a meta-analysis. Otolaryngol Head Neck Surg. 2010;143(1):17-25.

28. Zhao JZ, Gao M, Yu Y, Li YG, Li XL, Wei SF, et al. Harmonic scalpel versus conventional resection in thyroid surgery: a meta analysis on the safety outcomes. Zhonghua Er Bi Yan Hou Tou Jing Wai Ke Za Zhi. 2013;48(9):752-7.

29. Garas G, Okabayashi K, Ashrafian H, Shetty K, Palazzo F, Tolley N, et al. Which hemostatic device in thyroid surgery? A network meta-analysis of surgical technologies. Thyroid. 2013;23(9):1138-50.

30. Amaral JF, Hinoul P, Schwiers ML, Clymer JW. Comment on Garas et al., "Which hemostatic device in thyroid surgery? A network meta-analysis of surgical technologies". Thyroid. 2014;24(4):778-9.

31. Rubino LJ, Konstantakos EK, Stills Jr HF, Dudley ES, Grunden BK, Malaviya P. Healing of iatrogenic skeletal muscle wounds is affected by incision device. Surg Innov. 2010;17(2):85-91.

32. Chen C, Kallakuri S, Vedpathak A, Chimakurthy C, Cavanaugh JM, Clymer JW, et al. The effects of ultrasonic and electrosurgery devices on nerve physiology. Br J Neurosurg. 2012;26(6):856-63.

33. Nanduri $B$, Pendarvis $K$, Shack LA, Kumar R, Clymer JW, Korvick DL, et al. Ultrasonic incisions produce less inflammatory mediator response during early healing than electrosurgical incisions. PLoS One. 2013;8(9), e73032.

34. Wu CW, Dionigi G, Sun H, Liu X, Kim HY, Hsiao PJ, et al. Intraoperative neuromonitoring for the early detection and prevention of RLN traction injury in thyroid surgery: a porcine model. Surgery. 2014;155(2):329-39.

35. Bertke BDSP, Welling AL, Widenhouse TV, Chen C, Kallakuri S, Cavanaugh $\mathrm{JM}$, et al. Ex vivo and in vivo evaluation of an ultrasonic device for precise dissection, coagulation, and transection. Open Access Surgery. 2014;8:1-7.

\section{Submit your next manuscript to BioMed Central and take full advantage of:}

- Convenient online submission

- Thorough peer review

- No space constraints or color figure charges

- Immediate publication on acceptance

- Inclusion in PubMed, CAS, Scopus and Google Scholar

- Research which is freely available for redistribution

Submit your manuscript at www.biomedcentral.com/submit 